\title{
ORIGINAL ARTICLE \\ First data on bats (Chiroptera) for Vlora bay and Sazan Island, Albania
}

\author{
Philippe Théou ${ }^{1, *}$, Ervis Loce ${ }^{1}$
}

\begin{abstract}
${ }^{1}$ Department of Biology, Faculty of Natural Sciences, University of Tirana, Tirana 1001, Albania.

*Corresponding author: p.theou@gmail.com
\end{abstract}

DOI: https://doi.org/10.14709/ BarbJ.10.1.2017.04

Keywords: chiroptera, Albania, Sazan, island

received: April, 7th 2017 accepted: August, 10th 2017

\begin{abstract}
With 32 species recorded so far, Albania is one of the most important European countries in terms of bat diversity. However available data concerning the repartition of these species within the country is still very limited. For the first time, researches on bats were conducted in a key area of the country for biodiversity: Vlora Bay. During 5 years (2012-2016), at least 16 species (Rhinolophus ferrumequinum, R. hipposideros, R. blasii, R. euryale, Myotis oxygnatus, M. capaccinii, M. emarginatus, Nyctalus leisleri, N. noctula, Pipistrellus kuhlii, $P$. pipistrellus, P. pygmaeus, Hypsugo savii, Plecotus kolombatovici, Miniopterus schreibersii, Tadarida teniotis) were recorded in diverse habitats, including the main island of the country: Sazan Island. With this study we are providing new data for rarely recorded species such as P. kolombatovici and N. leisleri, and enriching available data on bats in the South-West Balkans. This study aims to support the implementation of conservation plans in Albania and to consolidate national monitoring of these protected species.
\end{abstract}

\section{INTRODUCTION}

Few studies have been devoted to bat ecology and conservation in Albania. In fact, only four studies were published before 1990 (Hanak et al. 1961, Hurka 1962, Hanak 1964, Lamani 1970) and since then bat research has been limited and has targeted only a few localities across the country (Bego \& Griffiths 1994, Chytil \& Vlasin 1994, Uhrin et al. 1996). Yet, the few studies conducted to date have much improved knowledge on Albanian bats and have fostered the protection of the 32 species recorded so far in the country (Sachanowicz \& Ciechanowski 2006, Sachanowicz et al. 2006, Schieffler et al. 2013, Théou et al. 2015a, Théou et al. 2015b, Théou 2015, Théou 2016).

Located on the western part of the country, Vlora bay is the largest bay in Albania. The area is composed by a mosaic of different habitats such as wetlands (Orikum, Narta), high mountains (up to 2044 meters) (Karaburun, Llogara), oak forests (Karaburun), olive tree plantations (Narta, Ionian sea coast), fir forests (Llogara) and coastal areas. Adjacent to the bay, the Island of Sazan (4,8 km long and $2 \mathrm{~km}$ wide) is characterized by an heterogeneous landscape composed by former urban areas (port and village) at the centre of the island, pine forests and Mediterranean maquis. The latter represents the main habitat in Sazan and the island has two important hills reaching $\mathbf{3 0 0}$ meters above sea level.

Both the Karaburun peninsula and the Island of Sazan have constituted a restricted military area for decades. However, since 2015, collaboration between the French Conservatoire du Littoral, the Albanian ministries of Defence and Environment, the University of Tirana and the Albanian
Coastal Agency has allowed the opening of the island to the public. Military activities have protected this region from the spread of massive urbanisation that has pragued much of the Mediterranean coastal areas. Additionally, hundreds of bunkers and tunnels built during communism period (19451990) are now often used as roosts by multiple bat species.

Despite the potential of the area for bats, no bat research was conducted in the area before 2012, especially due to the need for specific authorisations from the Ministry of Defence. Here, we present the first data on bats for Vlora bay and of Sazan Island.

\section{MATERIAL AND METHODS}

Since 2012, ten field work sessions were conducted in the area, including two surveys during the hibernating period of bats. Two different mist-nets $(3 m * 3 m$ and $5 m * 3 m)$ were used during five nights (Svërnec Island, coastal tunnel in Narta protected area, Sazan Island - Bunker with Water, Sazan Island $-8^{\text {th }}$ November School, Llogara Park). Bat identification of captured bats followed Dietz \& von Helversen (2004). Bones of dead bats were collected and additional information concerning the use of the sites by bats (guano, owl pellets, prey remains - e.g. wings of moths) was recorded. When large bat clusters were encountered, a photo was taken and the number of individuals was counted from the image. This method allowed to minimize disturbance to the colony.

In addition, a hand held bat detector (Pettersson D1000x) was used to record bat echolocation calls. Species identification was conducted using BatSound 4.11 following 


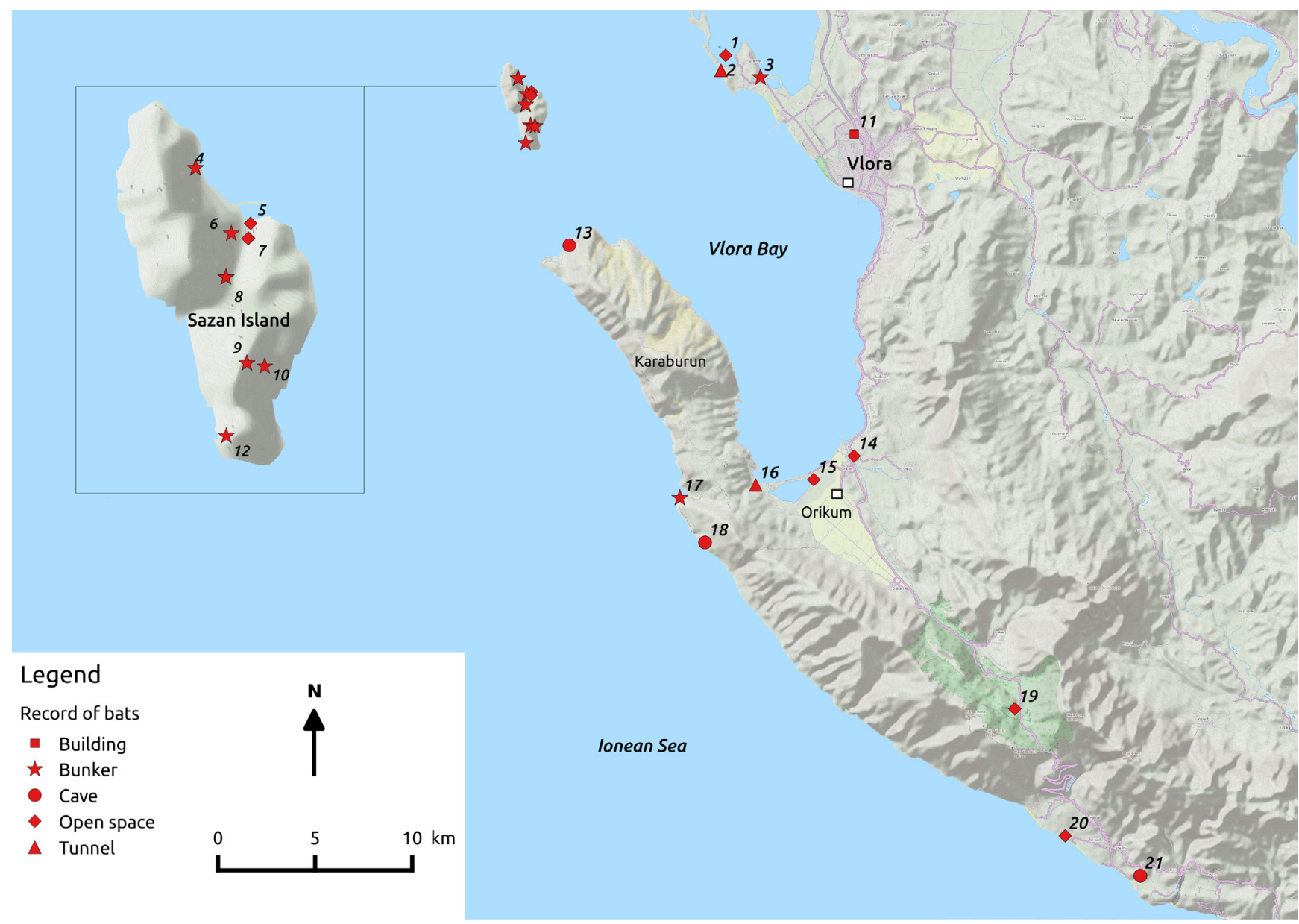

Fig. 1 - Sites where bats were recorded in Vlora Bay and Sazan Island between 2004 and 2016.

Russo \& Jones (2002), Papadatou et al. (2008) and Barataud (2014).

Key sites were visited several times between 2012 and 2016. In addition of the newly collected data, a data recorded in 2004 was included in the bibliography (Belmonte et al. 2006). In this article dealing with geology, a picture of a bat was including without any specific mention concerning the species.

\section{RESULTS AND DISCUSSION}

In total, eighty-four sites were visited during the period of this study. Twenty-one if these sites were occupied by bats (Table 1, Fig. 1 ) and at least 16 species were recorded (* species recorded on Sazan Island): Rhinolophus ferrumequinum, R. hipposideros, R. blasii, R. euryale, Myotis oxygnatus*, M. capaccinii, $M$. emarginatus, Nyctalus leisleri*, N. noctula*, Pipistrellus kuhlii*, P. pipistrellus*, P. pygmaeus*, Hypsugo savii*, Plecotus kolombatovici*, Miniopterus schreibersii, Tadarida teniotis*. Out of these 16 species, 9 species were recorded on Sazan Island. One species, P. kolombatovici, was only found on Sazan Island (Table 2).

\section{Rhinolophus ferrumequinum (Schreber, 1774)}

Rhinolophus ferrumequinum was found in a total of five sites (cave, tunnel and bunker), mainly in the Narta protected area and at the start of the Karaburun peninsula.
No maternity colony was found, and no specimens were recorded during the visit of the Narta lagoon in winter.

The absence of the Rhinolophidae, and especially $R$. ferrumequinum, from the Sazan Island was surprising. Especially considering the presence of hundreds of tunnels and bunkers that could be used as roosts by these species, as it is the case on the mainland (Théou \& Bego 2014). Despite the record of important colonies of Rhinolophidae in the mainland and the fact that the closest record of $R$. ferrumequinum took place only $6 \mathrm{~km}$ away from the island, no Rhinolophus bats were recorded during the three different sampling sessions conducted on the island. The distance between the island and the continent as well as the lack of water reserves on the island could be the reasons for its absence.

\section{Rhinolophus hipposideros (Bechstein, 1800)}

Recorded in four sites, this species was using the same roosts than Rhinolophus ferrumequinum with specimens recorded in caves, tunnels and bunkers. One maternity colony was recorded in the Narta protected area, with two juveniles photographed early July 2015. No specimens were recorded during winter period.

\section{Rhinolophus blasii (Peters, 1867)}

The data collected on Rhinolophus blasii during this study is of high importance of the south-west Balkans. With 
Table 1 - Sites where bats were recorded in Vlora Bay and Sazan Island between 2004 and 2016.

\begin{tabular}{|c|c|c|c|c|c|}
\hline ID & Name of the site & $\begin{array}{l}\text { Lat } \\
\text { WC }\end{array}$ & $\begin{array}{l}\text { Long } \\
84 \\
\end{array}$ & Type of site & Protection \\
\hline 1 & Svërnec Island & 40.51 & 19.40 & Open Space & \multirow{3}{*}{$\begin{array}{l}\text { Narta Lagoon } \\
\text { Protected Area }\end{array}$} \\
\hline 2 & Coastal Tunnel & 40.51 & 19.39 & Tunnel & \\
\hline 3 & Isolated Bunker & 40.50 & 19.42 & Bunker & \\
\hline 4 & Sazan Island - Bunker with water & 40.50 & 19.27 & Bunker & \\
\hline 5 & Sazan Island - Port & 40.50 & 19.28 & Open Space & \\
\hline 6 & Sazan Island - Bunker near cross-road & 40.49 & 19.28 & Bunker & \\
\hline 7 & Sazan Island - School 8th November & 40.49 & 19.28 & Open Space & \\
\hline 8 & Sazan Island - Bunker near hospital & 40.49 & 19.27 & Bunker & \\
\hline 9 & Sazan Island - Bunker on top of the hill & 40.48 & 19.28 & Bunker & \\
\hline 10 & Sazan Island - Bunker near road for southern part & 40.48 & 19.28 & Bunker & \\
\hline 11 & Parking & 40.48 & 19.47 & Building & \\
\hline 12 & Sazan Island - Bunker near southern building & 40.47 & 19.27 & Bunker & \\
\hline 13 & Shpella e Haxhi Alisë & 40.43 & 19.30 & Cave & $\begin{array}{c}\text { Natural Monument } \\
\text { Karaburun Natural Park }\end{array}$ \\
\hline 14 & Olive trees near national road & 40.33 & 19.47 & Open Space & \\
\hline 15 & Orikum Lagoon & 40.32 & 19.45 & Open Space & \\
\hline 16 & Tunnel in the back of the Military Port & 40.31 & 19.41 & Tunnel & \\
\hline 17 & Bunker on Duk Gjonit cave trail & 40.31 & 19.37 & Bunker & Karaburun Natural Park \\
\hline 18 & Shpella Duk Gjonit & 40.29 & 19.38 & Cave & $\begin{array}{c}\text { Natural Monument } \\
\text { Karaburun Natural Park }\end{array}$ \\
\hline 19 & Meadow in the middle of the forest & 40.21 & 19.57 & Open Space & Llogara National Park \\
\hline 20 & Drimades beach & 40.15 & 19.60 & Open Space & \\
\hline 21 & Shpella e Parashqevise & 40.13 & 19.65 & Cave & \\
\hline
\end{tabular}

more than 200 specimens, the maternity colony found in the Shpella e Parashqevise (Fig. 2) is one of the biggest ones identified in the western Balkans (Pavlinić et al. 2010, Presetnik et al. 2014). Specimens of $R$. blasii were mixed with R. euryale, Myotis emarginatus and M. schreibersii. However, $90 \%$ of the ultrasounds emitted by Rhinolophidae recorded inside the cave in July 2016 were around $93 \mathrm{kHz}$, allowing us to clearly identify the species. Also, despite the fact that clear identification was not possible during the survey, it is possible that at least some of the recorded specimens in September 2016 were R. blasii. This would suggest that the cave is perhaps used during most of the year by the species. We do not know yet if this cave is being used as a hibernation site. We highlight that the most important hibernation site known so far for this species in Albania is located $20 \mathrm{~km}$ north to the cave now identified (Théou et al. 2015).

\section{Rhinolophus euryale (Blasius, 1853)}

In addition of the Parashqevise cave, specimens of this species have been found in important numbers at the Duk Gjonit cave. This cave might be used as maternity colony by this species. We collected three owl pellets at the entrance of the cave in which one skull of Rhinolophus spp. was found. This indicates that predation by owls is happening in the area.

\section{Rhinolophus spp. (middle sized)}

During the surveys it was sometimes not possible to clearly identify bats as Rhinolophus euryale or R. blasii (some specimens were found during winter and therefore were not manipulated). Others were found in high cave roofs when we were not equipped with a bat-detector. Additionally the above mentioned species Rhinolophus mehelyi (Matschie 1901) might also be using the area, as this species was recently identified in the country (Sachanowicz et al. 2016).

\section{Myotis oxygnatus Monticelli, 1885}

A post lactating female of Myotis oxygnatus was netted on the $10^{\text {th }}$ August 2016 on Sazan Island, at the limit between the port and the pine forest, on a small bridge. It is the first clear identification of a Myotis species on the island, however ultrasounds of Myotis sp. were recorded during the two previous missions to the island. This important record highlights the possible presence of a maternity colony on the island and it sheds light on the key-role that forest ecosystems could have for bat conservation on the island.

\section{Myotis myotis (Borkhausen, 1797) / Myotis oxygnatus Monticelli, 1885}

One specimen was photographed resting in the marine cave Haxhi Alisë at the end of the Karaburun peninsula. It 
Table 2 - Data on bats collected in Vlora Bay and Sazan Island (2004-2016). Method of identification: capture $\left({ }^{*}\right)$; visual( $\left.{ }^{* *}\right)$; acoustic(***). Numbers in box brackets [ ] correspond with numbers of site, see Table 1.

\begin{tabular}{|c|c|c|c|}
\hline \multicolumn{2}{|l|}{ Species / Taxons } & \multicolumn{2}{|l|}{ Species / Taxons } \\
\hline Rhinolophus ferrumequinum & $\begin{array}{l}\text { [2] } 10 \text { ind. }(03 / 07 / 15)^{*} \\
\text { [2] } 2(27 / 07 / 16)^{* *} \\
\text { [3] } 1(03 / 07 / 15)^{*} \\
\text { [3] } 1(24 / 02 / 16)^{* *} \\
\text { [3] } 1(27 / 07 / 16)^{* *} \\
\text { [16] } 1(26 / 04 / 13)^{* *} \\
\text { [17] } 1(30 / 04 / 16)^{* *} \\
\text { [18] } 4(30 / 04 / 16)^{* *} \\
\end{array}$ & Nyctalus noctula & [5] $1(09 / 08 / 16)^{* * *}$ \\
\hline Rhinolophus hipposideros & $\begin{array}{l}\text { [2] } 15(03 / 07 / 15)^{* *} \\
\text { [2] } 10(27 / 07 / 16)^{* *} \\
{[17] 12(30 / 04 / 16)^{* *}} \\
\text { [18] } 3(30 / 04 / 16)^{* *}\end{array}$ & Pipistrellus kuhlii & [5] $1(05 / 09 / 12) *$ \\
\hline \multirow[t]{2}{*}{ Rhinolophus blasii } & \multirow[t]{2}{*}{$\begin{array}{l}\text { [21] } 150(29 / 04 / 16)^{* * *} / * * \\
\text { [21] } 200(26 / 07 / 16)^{* * *}\end{array}$} & $\begin{array}{l}\text { Pipistrellus kuhlii/ } \\
\text { Pipistrellus nathusii }\end{array}$ & $\begin{array}{l}\text { [4] } 5(05 / 09 / 12) * * * \\
\text { [5] } 5(28 / 05 / 13) * * * \\
\text { [5] } 5(29 / 05 / 13) * * * \\
\text { [5] } 1(09 / 08 / 16) * * * \\
\text { [14] } 1(25 / 04 / 13) * * * \\
\text { [15] } 1(25 / 04 / 13) * * * \\
\text { [19] } 1(25 / 07 / 16) * * * \\
\text { [20] } 1(23 / 07 / 14) * * * \\
\text { [20] } 1(24 / 07 / 14) * * *\end{array}$ \\
\hline & & Pipistrellus pipistrellus & $\begin{array}{l}\text { [1] } 1(27 / 07 / 16)^{* * *} \\
\text { [4] } 4(05 / 09 / 12)^{* * *}\end{array}$ \\
\hline Rhinolophus euryale & $\begin{array}{l}{[18] 250(30 / 04 / 16)^{* * *}} \\
{[21] 80(29 / 04 / 16)^{* * *}} \\
{[21] 10(26 / 07 / 16)^{* * *}}\end{array}$ & Pipistrellus pygmaeus & [4] $1(04 / 09 / 12) * * *$ \\
\hline $\begin{array}{l}\text { Rhinolophus euryale/ } \\
\text { Rhinolophus blasii }\end{array}$ & $\begin{array}{l}\text { [2] } 5(03 / 07 / 15)^{* *} \\
{[18] 300(29 / 09 / 15)^{* *}} \\
{[18] 49(25 / 01 / 16)^{* *}} \\
\text { [21] } 500(29 / 09 / 16)^{* *}\end{array}$ & Pipistrellus sp. & [11] $20(03 / 07 / 15)^{* *}$ \\
\hline Myotis oxygnathus & [7] $1(10 / 08 / 16) *$ & Hypsugo savii & $\begin{array}{l}\text { [1] } 1(27 / 07 / 16) * * * \\
\text { [4] } 1(05 / 09 / 12) * * * \\
\text { [4] } 1(28 / 05 / 13) * * * \\
\text { [4] } 1(09 / 08 / 16) * \\
\text { [5] } 1(09 / 08 / 16) * * * \\
\text { [15] } 1(25 / 04 / 13) * * * \\
\text { [19] } 1(25 / 07 / 16) * * * \\
\text { [20] } 1(23 / 07 / 14) * * *\end{array}$ \\
\hline $\begin{array}{l}\text { Myotis myotis/ } \\
\text { Myotis oxygnathus }\end{array}$ & $\begin{array}{l}{[13] 1(29 / 09 / 04)^{* *}} \\
{[18] 1(30 / 04 / 16)^{* *}}\end{array}$ & Plecotus kolombatovici & $\begin{array}{l}\text { [6] } 1(10 / 08 / 16) * \\
\text { [8] } 3(02 / 09 / 12) * * \\
\text { [8] } 1(27 / 05 / 13) * \\
\text { [8] } 1(09 / 08 / 16) * \\
\text { [9] } 1(02 / 09 / 12) * * \\
\text { [10] } 2(02 / 09 / 12) *\end{array}$ \\
\hline Myotis capaccinii & [21] $150(29 / 04 / 16) * *$ & Plecotus sp. & [4] $1(02 / 09 / 12) * * *$ \\
\hline Myotis emarginatus & $\begin{array}{l}{[18] 5(30 / 04 / 16)^{* *}} \\
{[21] 50(29 / 04 / 16) * *}\end{array}$ & Miniopterus schreibersii & $\begin{array}{l}\text { [18] } 40(30 / 04 / 16)^{* *} \\
{[21] 30(29 / 04 / 16)^{* *}} \\
{[21] 20(25 / 09 / 16)^{* *}}\end{array}$ \\
\hline Myotis sp. & $\begin{array}{l}\text { [4] } 1(05 / 09 / 12) * * * \\
\text { [4] } 1(28 / 05 / 13) * * * \\
\text { [5] } 1(09 / 08 / 16) * * * \\
\text { [20] } 1(23 / 07 / 14)^{* * *} \\
\text { [20] } 1(24 / 07 / 14) * * *\end{array}$ & Tadarida teniotis & $\begin{array}{l}\text { [1] } 1(27 / 07 / 16)^{* * *} \\
\text { [5] } 1(09 / 08 / 16)^{* * *} \\
\text { [7] } 1(28 / 05 / 13)^{* * *} \\
\text { [7] } 1(29 / 05 / 13)^{* * *} \\
\text { [19] } 1(25 / 07 / 16)^{* * *}\end{array}$ \\
\hline Nyctalus leisleri & $\begin{array}{l}\text { [9] } 1(28 / 05 / 13) * * * \\
\text { [15] } 1(25 / 04 / 13) * * *\end{array}$ & Unidentified & [12] $1(02 / 09 / 12)^{* *}$ \\
\hline
\end{tabular}


was identified via a picture published in Belmonte et al. (2006) which does not allow an exact identification of the species. The second specimen was observed in April 2016 in the Duk Gjonit cave, on the roof of the cave.

\section{Myotis capaccinii (Bonaparte, 1837)}

This species was found only in one site where it was mixed in an important cluster of Myotis schreibersii, $M$. emarginatus, Rhinolophus blasii and $R$. euryale at the end of April. Some specimens might use the cave during the rest of year, but no specimens were recorded during the two additional visits in July and September.

\section{Myotis emarginatus (Geoffroy, 1806)}

All the specimens of this species were recorded in caves in the southern part of the study area. They were forming clusters mainly with Rhinolophus blasii and $R$. euryale but have been found also with Myotis capaccinii and $M$. schreibersii. No maternity colony was clearly recorded during the study.

\section{Nyctalus leisleri (Kuhl, 1817)}

Our records represent the first mentions of Nyctalus leisleri in Albania since 1966 (Lamani 1970) and the first record of the species in the south of the country. Like most of the forest species of bats in Albania, this specie has not yet been targeted by any specific study in the country and its distribution is not well known. However, the presence of this species on Sazan Island underlines the need for conservation and good management plans of the island's forest.

\section{Nyctalus noctula (Schreber, 1774)}

Nyctalus noctula is the most common species of Nyctalus in Albania (pers. obs.). It has been recorded only once in the area on the Island of Sazan, where we recorded ultrasounds of at least one specimen foraging.

\section{Pipistrellus kuhlii (Kuhl, 1817)}

All the pellets collected on Sazan island were analysed as they represent an interesting way to improve the knowledge about bat population (Vale et al. 2015). Pipistrellus kuhlii has been clearly identified on the island thanks to owl pellets (most probably Athene noctua) collected near the port (Fig. 3). Additionally, ultrasounds have been recorded in six sites across the entire study area but due to the absence of social calls, Pipistrellus kuhlii and P. nathusii (Keyserling \& Blasius 1839) could not be separated.

\section{Pipistrellus pipistrellus (Schreber, 1774)}

The species has been recorded foraging in the forest of the Island of Svërnec (Narta protected area) as well as in the north of the Sazan Island, near one of the island's few water reservoirs.

\section{Pipistrellus pygmaeus (Leach, 1825)}

Sound calls of this species were recorded on Sazan Island, in the same location than P. pipistrellus and P. kuhlii/ nathusii.

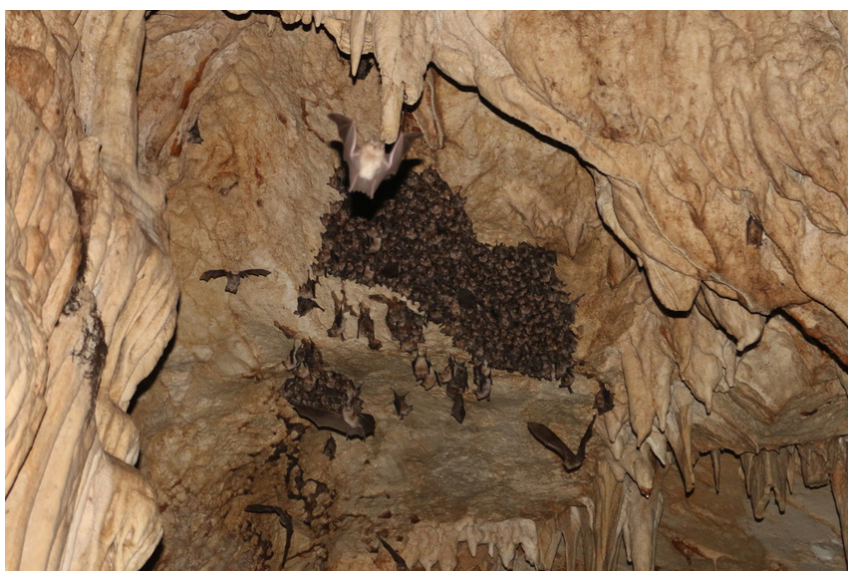

Fig. 2 - Part of the mixed colony of Rhinolophus blasii, R. euryale, $M$. emarginatus and Myoti schreibersii in the Parashqevise cave in July 2016 (Photo by P. Théou)

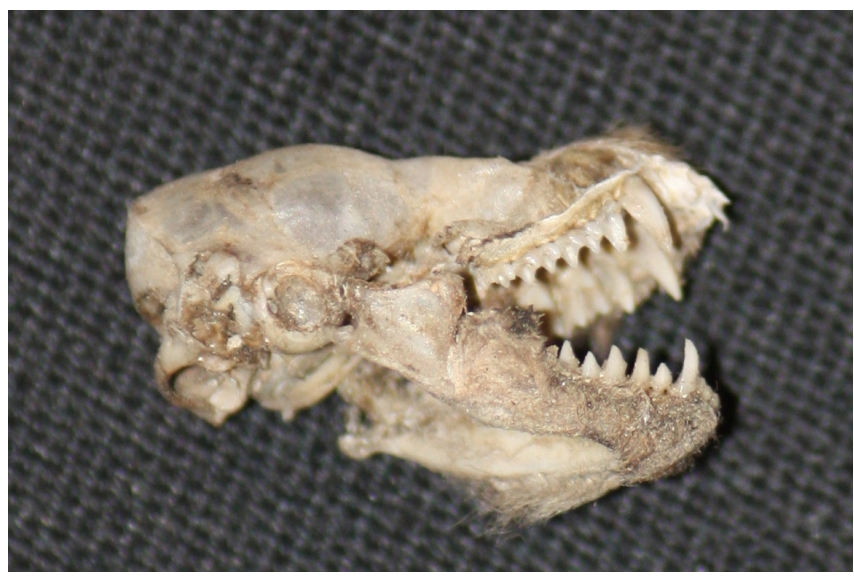

Fig. 3 - Skull of Pipistrellus kuhlii found in an owl pellet on Sazan Island (Photo by P. Théou)

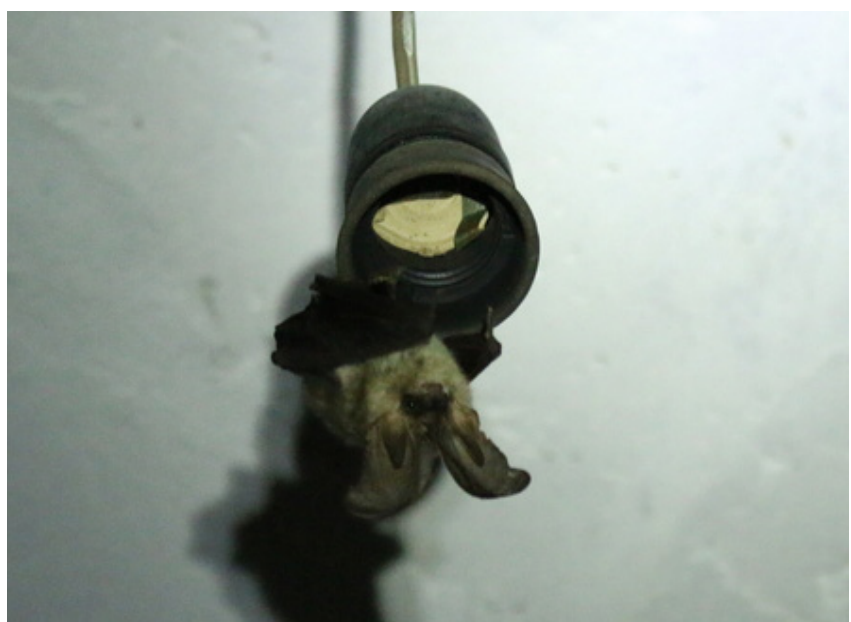

Fig. 4 - Plecotus kolombatovici in a bunker in the Island of Sazan (Photo by P. Théou)

\section{Hypsugo savii (Bonaparte, 1837)}

With records in six sites from the north to the south of the study area, $H$. savii is the most widespread species. In addition to ultrasound records, one male was captured in the north of Sazan Island on August 2016. 


\section{Plecotus kolombatovici (Dulic, 1980)}

All the specimens recorded in the area are from Sazan Island, which is the third place in Albania where the species was recorded. The presence of this species in a small island on the Adriatic coast is similar to the data collected in the western Balkans previously (Tvrtkovic et al. 2005). However, all the specimens recorded during this study seem to be using bunkers during most of the year (Fig. 4). This is interesting, as mainland populations have never been recorded in bunkers. The use of bunkers might be explained by the lack of competition for these artificial roosts, as most of the species using such habitats on the mainland have not been recorded in the island (Rhinolophidae, Miniopterus schreibersii and Myotis capaccinii) (Théou \& Bego 2014) were not recorded on the island. However, this hypothesis would need further research (there's only 11 mentions of this species in the country, including the 9 records of this study).

\section{Miniopterus schreibersii (Kuhl, 1817)}

The population of this species is limited to the two main caves of the area: Duk Gjonit and Parashqevise. No maternity colony has been recorded but additional surveys during the months of May and June might confirm the presence of juveniles in both of these caves.

\section{Tadarida teniotis (Rafinesque, 1814)}

This species has been found in most of surveyed habitats, which may be explained by its ability to hunt at high altitudes, allowing a relative disconnection with land cover (Marques et al. 2004). Vlora Bay and Sazan Island represent the second most important area in terms of data collected at the national scale, after the Prespa Lake National Park (Théou et al. 2015a). This may relate to the important concentration of cliffs, including in the northern part of Sazan Island, where the species may roost (Ancillotto et al. 2014).

\section{CONCLUSIONS}

The collected data highlight the high diversity of bats species in Vlora bay, with at least 16 species. However, the description of the region's bat population is likely incomplete and further surveys have the potential to unveil new bat taxa for the region. Winter expeditions and visits to Sazan Island and localities south of the area now sampled might be particularly important to gain new insights of the bat populations of the region. This will allow the implementation of better conservation plans, as well as a better integration of the area in the regional network of bat conservation.

The number of species recorded so far on Sazan Island corresponds, in average, to the number of species recorded in others small islands in Mediterranean (Bastelica et al. 2014). However, considering that several species recorded on the mainland seem to be absent from the island, the implementation of a monitoring plan in the next years would help understand if they are in fact absent and potentially aid to uncover the reasons behind their absence. This would help estimate whether the absence of these species is due to the relatively recent end of military activities or if it is rather linked with ecological issues (such as water limitations or due to the distance from the mainland) or if it is linked with the still very limited research efforts.

Many of the region's roosts and habitats are currently under threat and the pressure might increase in the near future. The illegal destruction of bunkers and tunnels on the mainland, as well as their use as dumpsites, represents an important conservation challenge to many roosts used by bats (Narta and Karaburun). In addition, bats could be subjected to important disturbances due the opening of caves to the public, like the Duk Gjonit and Haxhi Alisë caves, despite their status of natural monument which normally do not allow such activities. To solve these issues several projects were implemented to improve the protected area administrations and the civil society management capacities.

This study is an important contribution to the knowledge of bat population in the south of Albania. Yet, additional surveys and monitoring should be undertaken not only to investigate new colonies but also to identify potential conservation problems in already identified important areas for bat conservation.

\section{ACKNOWLEDGEMENTS}

Part of the data has been collected during the following projects: EU funded project IPA-10 "Consolidation of the Environmental Monitoring System in Albania" (CEMSA Project), "Mediterranean Small Islands Initiative" (PIM Initiative) implemented by the Conservatoire du Littoral, EU funded project IPA-13 "NaturAI", CEPF funded project "Caves of the Karaburun Peninsula" implemented by PPNEA and Flag Pine NGOs.

The authors would like to thank Genuario Belmonte who shared his data concerning Haxhi Alisë cave. The authors would like to thank all the people that helped during the last six years to increase the knowledge of the bats in Albania, especially Celine Damery, Ferdinand Bego, Mirjan Topi, Caterina Carugati, all the staff of the protected areas of the Vlora area, including Lorela Lazaj and Nexhip Hysolakoj, Saimir Beqiraj, Amarilda Rapaj, Colette Donadio, Paolo Fraccaro and Marcesa Kotoni.

\section{REFERENCES}

ANCILLOTTO, L., RYDELL, J., NARDONE, V. \& RUSSO, D. (2014). Coastal cliffs on islands as foraging habitat for bats. Acta Chiropterologica, 16(1): 103-108. https://doi. org/10.3161/150811014X683318

BARATAUD, M. (2014). Écologie acoustique des chiroptères d'Europe: identification des espèces, étude de leurs habitats et comportements de chasse. 2e éd. Biotope, Mèze; Mèze Muséum national d'Histoire naturelle, Paris, France, 344 pp.

BASTALICA, F., DAMERY, C., \& ALLEGRINI, B. (2014). Y-a-til des chiroptères sur les petites îles Méditerranéennes Françaises? 15ème Rencontres nationales chauvessouris de la SFEPM. Bourges, France. 
BEGO, F. \& GRIFFITHS, H.I. (1994). Preliminary data on the bats (Mammalia, Chiroptera) of Albania. Studies in Speleology, 9: 21-25.

BELMONTE, G., COSTANTINI, A., MOSCATELLO, S., DENITTO, F. \& SHKURTAJ, B. (2006). Le grotte sommerse della penisola del Karaburun (Albania): primi dati. Thalassia Salentina, 29 (suppl.): 15-28. https://doi. org/10.1285/i15910725v29supp15

CHYTIL, J., \& VLASIN, M. (1994). Contribution to the knowledge of bats (Chiroptera) in Albania. Folia Zoologica, 43(4): 465-467.

DIETZ, C., \& VON HELVERSEN, O. (2004). Illustrated identification key to the bats of Europe. Tuebingen \& Erlangen, Germany, 73pp.

HANAK, V., LAMANI, F., \& MURAJ, X. (1961). Të dhëna nga përhapja e lakuriqëve të natës (Chiroptera) në Shqiperi. Buletin I Universitetit Shteteror Te Tiranes. Seria Shkencat Mjekesore. Natyrore, 3: 124-158.

HANAK, V. (1964). Zur Kenntnis der Fledermäuse fauna Albaniens. Vestnik Zoologii, 28: 68-88.

HURKA, K. (1962). Beitrag zur Nycteribiiden -und Strebli denfauna Albaniens nebst Bemerkungen zur Fauna von Bulgarien; Ungarn und UdSSR. Acta Societatis Entomologicae Cechosloveniae, 59(2): 156-164.

LAMANI, F. (1970). Lloje të reja lakuriqesh nate në vëndin tonë. Buletini i Shkencave Natyrore, 2: 43-150.

MARQUES, J.T., RAINHO, A., CARAPUÇO, M., OLIVEIRA, P., \& PALMEIRIM, J.M. (2004). Foraging behaviour and habitat use by the European free-tailed bat Tadarida teniotis. Acta Chiropterologica, 6(1): 99-110. https://doi. org/10.3161/001.006.0108

PAPADATOU, E., BUTLIN, R. K., \& ALTRINGHAM, J. D. (2008). Identification of bat species in Greece from their echolocation calls. Acta Chiropterologica, 10(1): 127143. https://doi.org/10.3161/150811008X331153

PAVLINIĆ, I., ĐAKOVIĆ, M., \& TVRTKOVIĆ, N. (2010). The Atlas of Croatian Bats, Part I. Natura Croatica, 19(2): 295337.

PRESETNIK, P., PAUNOVIĆ, M., KARAPANDŽA, B., ĐUROVIĆ, M., IVANOVIĆ, Č., ŽDRALEVIĆ, BENDA, P., BUDINSKI, I. (2014). Distribution of bats (Chiroptera) in Montenegro. Vespertilio, 17: 129-156.

RUSSO, D., \& JONES, G. (2002). Identification of twentytwo bat species (Mammalia: Chiroptera) from Italy by analysis of time-expanded recordings of echolocation calls. Journal of Zoology, 258(01): 91-103. https://doi. org/10.1017/S0952836902001231

SCHIEFFLER V. I., BEGO F., THÉOU P., PODANY M., POSPISCHIL R., \& HUBNER S. (2013). Ektoparasiten der Fledermäuse in Albanien - Artenspektrum und Ëirtsbindung. Nyctalus, 18(1): 84-109.
SACHANOWICZ, K., \& CIECHANOWSKI, M. (2006). Plecotus macrobullaris - new bat species for Albanian fauna. Lynx, 37: 241-246.

SACHANOWICZ, K., CIECHANOWSKI, M., \& RACHWALD, A. (2006). Supplementary notes on the distribution of Pipistrellus pipistrellus complex in the Balkans: first records of $P$. pygmaeus in Albania and in Bosnia and Herzegovina. Lynx, 37: 247-254.

SACHANOWICZ, K., CIECHANOWSKI, M., RACHWALD, A., \& PISKORSKI, M. (2016). Overview of bat species reported in Albania with the first country records for eight species. Journal of natural history, 50(7/8): 513521. https://doi.org/10.1080/00222933.2015.1059962

THÉOU P., \& BEGO F. (2014). First bat monitoring in Albania: bunkers of Tirana, picture of bat conservation in Albania. Buletini i Shkencave Natyrore, 18: 76-83.

THÉOU, P., LOÇE, E., \& BEGO, F. (2015a). New data on bats (Chiroptera) in the Albanian National Park of Prespa Lakes. Buletini i Shkencave Natyrore, 19: 79-98.

THÉOU, P., LOÇE, E.,\& ĐUROVIĆ, M. (2015b). Results of the pioneer survey of potential bat hibernacula in Albania (2012-2015). Natura Sloveniae, 17(1): 25-39.

THÉOU, P. (2015). Bat Populations in Albania: Structure and Dynamic of Populations. Thesis. University of Tirana. 79 pp.

THÉOU, P. (2016). Putative predation of Miniopterus schreibersii (Vespertilionidae, Chiroptera) by Zamenis longissimus (Colubridae, Reptilia) in the Albanian National Park of Prespa Lakes. Mammalia, 80(5): 571572. https://doi.org/10.1515/mammalia-2015-0003

TVRTKOVIĆ, N., PAVLINIĆ, I., \& HARING, E. (2005). Four species of long-eared bats (Plecotus, Geoffroy, 1818; Mammalia, Vespertilionidae) in Croatia: field identification and distribution. Folia Zoologica, 54(1/2): 75-88.

UHRIN M., HORÁČEK I., ŠIBL J., \& BEGO F. (1996). On the bats (Mammalia: Chiroptera) of Albania: survey of the recent records. Acta Societatis Zoologicae Bohemicae, 60: 63-71.

VALE-GONÇALVES H., BARROS P., BRAZ L., \& CABRAL J. A. (2015). The contribution of the Barn owl (Tyto alba) feeding ecology to confirm bat species occurrence in north Portugal. Journal of Bat Research \& Conservation, 8(1): 22-26. http://dx.doi.org/10.14709/BarbJ.8.1.2015.05 